Article

\title{
Carbon Input and Maize Productivity as Influenced by Tillage, Crop Rotation, Residue Management and Biochar in a Semiarid Region in South Africa
}

\author{
Patrick Nyambo ${ }^{\circledR}$, Cornelius Chiduza * and Tesfay Araya \\ Department of Agronomy, University of Fort Hare, Private Bag X1314, Alice 5700, South Africa; \\ pnyambo@ufh.ac.za (P.N.); TWeldeslassie@ufh.ac.za (T.A.) \\ * Correspondence: cchiduza@ufh.ac.za; Tel.: +27-789856220
}

Received: 16 April 2020; Accepted: 12 May 2020; Published: 14 May 2020

\begin{abstract}
Conservation agriculture (CA) as a system is still evolving on many of the smallholder farms in sub-Saharan Africa (SSA) and questions on the impact of individual components and pathways toward adoption still require answers. A short-term study was conducted to investigate the effect of tillage, crop rotation, and crop residue management, including maize residue biochar on above ground biomass, cumulative carbon (C) input, soil organic carbon (SOC), and maize grain yield. A split-split plot design was used to evaluate two tillage operations (conventional tillage (CT) and no-till (NT)), three crop rotations (maize-fallow-maize (MFM), maize-oat-maize (MOM), and maize-vetch-maize (MVM)), and three-crop residue management (retention $(\mathrm{R}+)$, removal $(\mathrm{R}-)$, and biochar (B)). The cumulative above ground biomass produced in the MOM rotation was significantly higher by $78.9 \%$ and $88.7 \%$ relative to MVM and MFM rotations, respectively. The cumulative $\mathrm{C}$ input under residue management treatments ranged from 10.65 to $12.16 \mathrm{Mg} \mathrm{ha}^{-1}$. The highest SOC was observed under $\mathrm{R}+(1.10 \%)$ followed by B $(1.0 \%)$ and the lowest was in $\mathrm{R}-$ $(0.96 \%)$. Crop residue management significantly affected grain yields in 2015/2016 $(p<0.05)$ and 2016/2017 $(p<0.01)$ summer seasons. Biochar did not result in an obvious improvement in both $\mathrm{C}$ input and crop yield. Smallholder farmers can potentially switch from CT to NT without any significant yield penalty, as well as adopt MOM and R+ practices for increased biomass and C input.
\end{abstract}

Keywords: conservation agriculture; biomass; cumulative carbon; biochar

\section{Introduction}

The poor adoption of conservation agriculture (CA) is a result of several socioeconomic and biophysical factors like availability, cost and knowledge associated with use of herbicides for purposes of weed control, lack of adapted implements for direct sowing and residue management tradeoffs in crop-livestock farming systems [1,2]. Crop rotation, minimal soil disturbance, and crop residue soil cover are all key elements for the success of CA [3]. Description of smallholder farmer practice of CA by many authors (e.g., $[1,4,5]$ ) shows that many adopt one or two of the principles but rarely all three [6]. This shows that Farmers are on a pathway towards CA and will undergo intermediary steps. Evaluation of interaction of factors involved in CA may reveal the best practices to promote a combination or steps that will assist to enhance improvement in early phases when there might be little visible evidence of change at field level. In this regard, a component omission experiment could be a useful tool. This approach can lead to the identification of informed and sustainable key entry points for potential adoption by the farmers [7,8].

Management practices have an important effect on the soil fertility and crop productivity [9]. Conservation agriculture is a sustainable agricultural practice because of its contribution to soil 
health and increased crop productivity [10]. It is based on three basic principles, namely, continuous minimum soil disturbances and/or no tillage (NT), maintenance of organic mulch, and diversified and economically viable crop rotations and plant associations [11,12]. The potential of CA is in soil and water conservation through its ability to increase and maintain soil organic carbon (SOC), the most crucial factor in soil quality [13]. Improvement of SOC was suggested as the major contributory factor to better nutrient availability and crop productivity under CA [14,15]. No-tillage reduces soil organic matter (SOM) decomposition, increasing the soil carbon (C) sequestration and soil quality [16]. On the other hand, conventional agricultural practices like soil tillage (CT) leads to soil structural damage and loss of SOC, which in turn results in a decline of soil fertility, reduced infiltration, increased runoff and erosion and, in many cases, reduced crop yields [17]. High biomass-yield cover crops are a key component for the success of CA as they play an important role in soil quality and reduce nonpoint sources of nutrient pollution [18]. High biomass translates to better weed management, soil moisture conservation, and fertility improvement, in addition to protection of soil from erosion [19]. Diagnostic studies, initiated and implemented by the Department of Agronomy at University of Fort Hare, to address the issue of low biomass, evaluated and assessed several winter and summer cover crops under the local conditions. The preliminary findings suggested vetch (Vicia dasycarpa) and white oat (Avena sativa) are the best species to yield high biomass under winter irrigation in Eastern Cape Province [19]. Thus, selection of oat and vetch was primarily based on their ability to produce high and persisting biomass for soil moisture conservation and weed control, and ability to meet part of the nutrient requirement of the subsequent crop [20].

Globally, much research evidence exists on the effects of CA on soil and crop productivity [21,22]. However, the results are inconsistent $[17,23]$. For example, in Northwest and South China, conservation agriculture increased crop yields by $6.4 \%$ and $5.5 \%$, respectively [24]. Araya et al. [25] reported similar results in the subhumid climatic conditions in Ethiopia. On the other hand, Mashingaidze et al. [26] observed no significant yield differences between $\mathrm{CT}$ and $\mathrm{NT}$ in the short term under semiarid climatic conditions in Zimbabwe. Also, Paul et al. [27] and Paudel et al. [28] reported no change in crop yields during the initial years of practicing CA. The yield differences in CA systems were largely owing to the differences between socioeconomic setup, crops, tillage implements and systems, soils, climate, and experiments in different parts of the world [25].

Whilst it is important to continue working on CA with smallholder farmers and to look at longer time frames for impact, it is also important to assess alternative practices that can drive up yields to a point where the system is productive enough and produces sufficient biomass to ensure successful practice of CA. Crop residues used as mulch are central to the success of moisture conservation, weed suppression, and SOM improvement, and as a result high soil and crop productivity [29]. However, one of the least adopted agricultural practices by smallholder farmers in the Eastern Cape is the retention of crop residues. Mostly, residues are burnt to clear the fields for tillage and planting or are grazed by livestock [30,31]. Grazing is sometimes ex situ to conserve the fodder for livestock in the lean season before the rains. In some cases the manure from the livestock is not returned to the same fields. Where grazing is in situ, little residue is left in the field to provide meaningful cover and soils deteriorate in quality, and yields decline as shown by analysis of Sub-Saharan Africa cereal yields over the last 50 years [32]. These practices led to soil erosion, environmental pollution, soil degradation, and reduction of soil organic matter [33]. It is therefore important to explore or investigate various residue management options that promote climate-smart agriculture in the central Eastern Cape (EC). One such residue management practice is production of biochar.

Use of biochar has been practiced by farmers in the rain forests of West Africa and in the Amazon for decades [34]. It is produced from a variety of biomass residues (feedstock) such as grasses, hard and soft wood, agricultural, and forestry residues [35,36]. Biochar recently attracted considerable interest as a sustainable technology to improve sequestering C, mitigating GHG, and improving the soil, thus reducing the problems and causes of climate change [37]. Generally, it has a high C content, larger surface area, and low density compared to crop residues. Its application to soils was shown to 
substantially enhance some parameters such as C content [38] and can increase soil fertility and crop productivity by reducing the leaching of nutrients or even supplying nutrients to plants [39]. Could use of the biochar approach be more appropriate compared to, for example, crop residue retention, in utilizing low biomass levels on smallholder farms in the central EC to improve biomass yields and productivity of the cropping systems?

Therefore, in this study, impact of tillage, crop rotation, and residue management, including production of biochar from maize residues, were investigated with focus on short term effects on SOC, aboveground biomass production, cumulative $C$ input, and grain maize yield in the Eastern Cape Province, South Africa.

\section{Materials and Methods}

\subsection{Site Selection}

Field experiments were conducted at the University of Fort Hare research farm, which is located at latitude $32^{\circ} 46^{\prime} \mathrm{S}$ and longitude $26^{\circ} 50^{\prime} \mathrm{E}$, at an altitude of $535 \mathrm{~m}$ above sea level (masl). The soils are deep and of alluvial origin, classified as Haplic Cambisol [40] and dominated by mica in the clay fraction [41]. The site has a warm temperate climate with a mean annual temperature of $18.1^{\circ} \mathrm{C}$ and an average annual rainfall of $575 \mathrm{~mm}$ received mainly during the summer months from November to March [42]. The soil type and climate at the research farm closely resemble those of smallholder farms in the vicinity of Alice, in the central EC. Prior to the establishment of the field trial, the field was planted to maize (Zea mays L.).

\subsection{Treatments and Experimental Design}

The experiment was initiated in the 2015 winter season and continued for six seasons until the 2018/2019 summer season when it was terminated (Table 1). It investigated three factors: tillage, crop rotation, and residue management in factorial combination, and was laid out as a split-split plot design. Tillage with two levels (no-tillage (NT) and conventional tillage (CT)) was allocated to the main plots. The subplots were allocated to rotations that were at three levels (maize-fallow-maize (MFM), maize-vetch-maize (MVM), and maize-oat-maize (MOM)). Sub-subplots were allocated to the residue management strategies at three levels (residue removal $(\mathrm{R}-$ ), crop residue retention $(\mathrm{R}+$ ), and biochar (B)). The main plots measured $17.75 \times 15 \mathrm{~m}^{2}$, the subplots were $5.25 \times 15 \mathrm{~m}^{2}$, and the sub-subplots were $5.25 \times 5 \mathrm{~m}^{2}$. The total area of the trial was $36.5 \times 55 \mathrm{~m}^{2}$. The gross plot measured $5.25 \times 5 \mathrm{~m}^{2}$ and the net plot was $2.25 \times 4 \mathrm{~m}^{2}$. The CT plots were ploughed to a depth of $30 \mathrm{~cm}$ once at the beginning of each season, April for winter planting and October for summer planting (Table 1), using a tractor-drawn disk plough and then harrowed to make a fine tilth.

Table 1. Summary of crops grown for the duration of the trial investigating the interaction of tillage, crop rotation, and crop residue management from 2015 to 2018.

\begin{tabular}{|c|c|c|c|c|c|c|}
\hline $\begin{array}{c}\text { Crop } \\
\text { Rotation }\end{array}$ & $\begin{array}{l}\text { Winter } 2015 \\
\text { (Season 1) }\end{array}$ & $\begin{array}{c}\text { Summer } \\
2015 / 2016 \\
\text { (Season 2) }\end{array}$ & $\begin{array}{c}\text { Winter } 2016 \\
\text { (Season 3) }\end{array}$ & $\begin{array}{c}\text { Summer } \\
2016 / 2017 \\
\text { (Season 4) }\end{array}$ & $\begin{array}{l}\text { Winter } 2017 \\
\text { (Season 5) }\end{array}$ & $\begin{array}{c}\text { Summer } \\
2017 / 2018 \\
\text { (Season 6) }\end{array}$ \\
\hline MFM & Fallow & Maize & Fallow & Maize & Fallow & Maize \\
\hline MOM & Oat & Maize & Oat & Maize & Oat & Maize \\
\hline MVM & Vetch & Maize & Vetch & Maize & Vetch & Maize \\
\hline
\end{tabular}

MOM, maize-oat-maize; MVM, maize-vetch-maize; MFM, maize-fallow-maize.

\subsection{Management of Nonexperimental Variables}

The winter cover crops were oat (Avena sativa cv. Sederbrg) and grazing vetch (Vicia dasycarpa cv. Max), planted at recommended seed rates of 90 and $35 \mathrm{~kg} \mathrm{ha}^{-1}$, respectively. Planting in both NT and CT plots was done making small furrows opened using hoes. Basal fertiliser for both cover crops was 
applied as a compound at planting at $10 \mathrm{~kg} \mathrm{P} \mathrm{ha}^{-1}$, as a compound (6.7\% N, 10\% P, 13.3\% K). Only the oat cover crop was top dressed at six weeks after planting using lime-ammonium (LAN) (28\% N) at a rate of $138 \mathrm{~kg} \mathrm{ha}^{-1}$ to make a total of $45 \mathrm{~kg} \mathrm{~N} \mathrm{ha}^{-1}$. The Rhizobium leguminosarium biovar viciae was used to inoculate the grazing vetch at planting. Glyphosate ( $N$-(phosphonomethyl) glycine, $\left.360 \mathrm{~g} \mathrm{~L}^{-1}\right)$ was applied ( $\left.5 \mathrm{~L} \mathrm{ha}^{-1}\right)$ to terminate the cover crops. At the end of each season, crop residues were retained, removed, or converted into biochar. In plots with the B treatment, all crop residues obtained in both the summer and winter seasons were pyrolysed using $200 \mathrm{~L}$ oil drum kilns as described by Nyambo et al. [36]. After cooling, the biochar was crushed and passed through a $2 \mathrm{~mm}$ sieve before being applied to the respective plots, before planting of the winter or summer crops. The total quantity of biochar applied in the study is shown in Table 2.

Table 2. Cumulative amount of biochar applied to the treatments in the study.

\begin{tabular}{cccc}
\hline & MFM & MVM & MOM \\
\hline Mg ha $^{-1}$ \\
Conventional tillage & 11.4 & 12.4 & 16.1 \\
No-tillage & 9.4 & 13.0 & 16.7 \\
\hline
\end{tabular}

MFM, maize-fallow-maize; MOM, maize-oat-maize; MVM, maize-vetch-maize.

Okavango, a yellow open pollinated maize variety (OPV) popular with smallholder farmers in the central Eastern Cape, was planted. The maize rows were spaced at a distance of 0.75 and $0.33 \mathrm{~m}$ to give a planting density of 44.444 plants ha ${ }^{-1}$. The maize rows were made by making small furrows opened using hoes. Fertilizer was applied in all the plots at a rate of $90 \mathrm{~kg} \mathrm{~N} \mathrm{ha}^{-1}, 45 \mathrm{~kg} \mathrm{P} \mathrm{ha}^{-1}$, and $60 \mathrm{~kg} \mathrm{~K} \mathrm{ha}^{-1}$. A compound fertilizer $(6.7 \% \mathrm{~N}, 10 \% \mathrm{P}, 13.3 \% \mathrm{~K},+0.5 \% \mathrm{Zn})$ was used to supply a third of the $\mathrm{N}$ and all the $\mathrm{P}$ and $\mathrm{K}$ needed by the maize crop [43]. The remaining nitrogen was side dressed at six weeks after planting as LAN. Pests were controlled in the maize and oat crops by using Cylam 50EC (lambda-cyhalothrin (pyrethroid), $50 \mathrm{~g} \mathrm{~L}^{-1}$ ). Supplementary irrigation was applied to both winter and summer crops when necessary (Table 3).

Table 3. Rainfall and irrigation water received during periods of summer maize and cover crops growth (2015-2017).

\begin{tabular}{cccccccccc}
\hline \multirow{2}{*}{ Month } & \multicolumn{3}{c}{ Rainfall } & \multicolumn{3}{c}{ Irrigation } & \multicolumn{3}{c}{$\begin{array}{c}\text { Temperature } \\
(\mathbf{m m})\end{array}$} \\
\cline { 2 - 10 } & $\mathbf{2 0 1 5}$ & $\mathbf{2 0 1 6}$ & $\mathbf{2 0 1 7}$ & $\mathbf{2 0 1 5}$ & $\mathbf{2 0 1 6}$ & $\mathbf{2 0 1 7}$ & $\mathbf{2 0 1 5}$ & $\mathbf{2 0 1 6}$ & $\mathbf{2 0 1 7}$ \\
\hline Jan & 75.7 & 25.2 & 89.9 & 0 & 40 & 25 & 22.7 & 23.9 & 21.5 \\
Feb & 124 & 85.3 & 73.2 & 0 & 20 & 30 & 22.2 & 22.6 & 22.04 \\
Mar & 83.5 & 75 & 34.3 & 0 & 20 & 20 & 20.3 & 20.8 & 21.21 \\
Apr & 65.5 & 43.3 & 22.1 & 0 & 0 & 0 & 16.1 & 18.5 & 18.24 \\
May & 7.2 & 7.6 & 18.7 & 0 & 0 & 0 & 15.6 & 15.5 & 16.22 \\
Jun & 33 & 13.2 & 2.8 & 0 & 30 & 0 & 12.1 & 13.6 & 13.35 \\
Jul & 92.5 & 43.9 & 4.3 & 0 & 0 & 30 & 11.2 & 12.5 & 12.35 \\
Aug & 20.8 & 10.9 & 66.0 & 0 & 30 & 0 & 14.4 & 15.4 & 13.03 \\
Sep & 60.7 & 32.8 & 23.1 & 0 & 25 & 0 & 15.3 & 15.6 & 15.92 \\
Oct & 17.5 & 18.3 & 84.8 & 50 & 0 & 0 & 18.5 & 17.1 & 16.16 \\
Nov & 72.6 & 40.3 & 91.7 & 30 & 25 & 20 & 19.2 & 18.9 & 17.8 \\
Dec & 1.8 & 14 & 48.3 & 40 & 55 & 20 & 22.7 & 22.7 & 19.02 \\
\hline
\end{tabular}




\subsection{Measurements}

Soil sampling was done soon after harvesting of each rotational crop. Before sampling, all crop residues and visible organic matter were removed. Three random composite samples were collected using a spade from the $0-5 \mathrm{~cm}$ depth and a $7 \mathrm{~cm}$ diameter auger was used for the 5-10 $\mathrm{cm}$ depth. The samples were taken to the laboratory in rigid containers to avoid breaking the soil aggregates. They were then air-dried and visible organic debris removed before laboratory work. These samples were used to measure SOC and total organic C.

\subsubsection{Aboveground Biomass Yields}

In each winter season, after termination, cover crop residues and weed samples were obtained from two quadrats measuring $35 \times 35 \mathrm{~cm}$ for estimation of aboveground biomass yield. The biomass was harvested by cutting at ground level. Samples were oven-dried at $60^{\circ} \mathrm{C}$ to a constant weight for determination of dry weight and further chemical analysis [44]. The seasonal aboveground biomass of the maize crop is reported in this study. Cumulative aboveground biomass was determined by summing all the biomass yield obtained in the six cropping seasons.

\subsubsection{Soil Organic Carbon and Carbon Input}

Soil organic carbon was determined following the modified Walkley-Black method as outlined in Agri Laboratory Association of Southern Africa [45]. Total soil C was measured using dried and ground plant and soil samples following the dry combustion method using a LECO TruSpec $\mathrm{C} / \mathrm{N}$ auto analyzer [46]. This was used to calculate the $C$ input by finding the product of the $C$ concentrations $(\%)$ and the dry weights of the crop biomass in the various treatments. Cumulative $\mathrm{C}$ input was determined by summing $\mathrm{C}$ input obtained in the six cropping seasons.

\subsubsection{Maize Yield and Yield Components}

Plant height was measured on five random plants per plot. Thousand grain weight was determined by counting a thousand maize grains and weighing [44]. Grain yield $\left(\mathrm{Mg} \mathrm{ha}^{-1}\right)$ was corrected to $12.5 \%$ moisture level.

\subsection{Data Analysis}

For all the parameters measured, data were subjected to an analysis of variance (ANOVA) using the JMP statistical package version 15.0 (SAS Institute, Inc., Cary, NC, USA). The seasons were tested for homogeneity using the Bartlett's test [47]. Non-significance indicated that the variances were homogenous; hence, combined analysis of variance was done. In cases where variance was heterogeneous, seasonal analysis was done. Where significant differences occurred, separation of means was done using the least significant difference (LSD) at the 0.05 level of significance.

\section{Results}

\subsection{Aboveground Biomass Production and Carbon Input}

Three-way interaction of tillage $\times$ crop rotation $\times$ residue management was not significant $(p>0.05)$ in relation to the maize crop aboveground biomass and cumulative aboveground biomass. Similarly, two-way interactions of tillage $\times$ crop rotation, tillage $\times$ crop residue management and crop rotation $\times$ crop residue management were not significant $(p>0.05)$ with respect to maize crop aboveground biomass and cumulative aboveground biomass. Only the main effects of crop rotation significantly $(p<0.001)$ affected cumulative biomass production. The cumulative biomass ranged from 22.83 to $40.08 \mathrm{Mg} \mathrm{ha}^{-1}$ and followed decreasing order of MOM $>$ MVM $>$ MFM (Figure 1).

There were no significant $(p>0.05)$ three-way and two-way interaction effects with respect to cumulative $C$ input. Two-way interactions of tillage $\times$ crop rotation, tillage $\times$ crop residue management, 
and crop rotation $x$ crop residue management were not significant $(p>0.05)$ with respect to cumulative $C$ input. The main effects of crop rotation and crop residue management significantly affected cumulative $C$ input at $p<0.001$ and $p<0.05$, respectively, whereas tillage had no effect $(p>0.05)$ on cumulative $C$ input in the study. The cumulative $C$ in the MOM rotation was $78.1 \%$ and $14.5 \%$ higher when compared to MFM and MVM treatment, respectively (Figure 2a). Retaining crop residues (12.2 $\left.\mathrm{Mg} \mathrm{ha}^{-1}\right)$ accounted for more cumulative $\mathrm{C}$ input relative to biochar $\left(110.1 \mathrm{Mgha}^{-1}\right)$ and residue removals (10.65 $\mathrm{Mgha}^{-1}$ ) (Figure 2b).

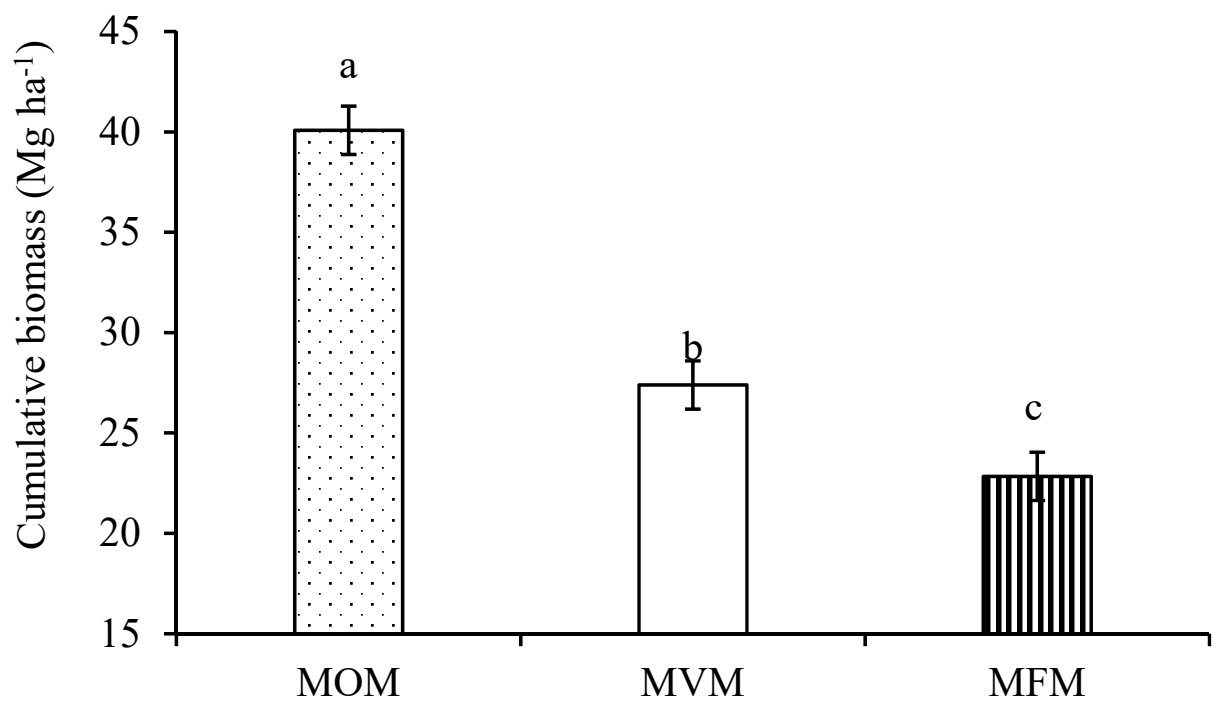

\section{Crop rotation}

Figure 1. Crop rotation effects on cumulative biomass production $\left(\mathrm{Mg} \mathrm{ha}^{-1}\right)$ for six seasons (2015-2017). Different lowercase letters indicate significant differences at $p<0.001$.

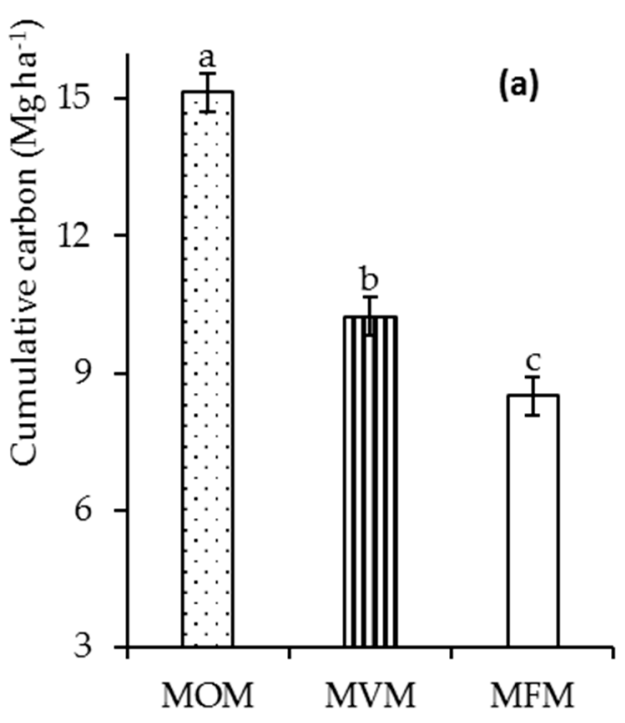

Crop rotation

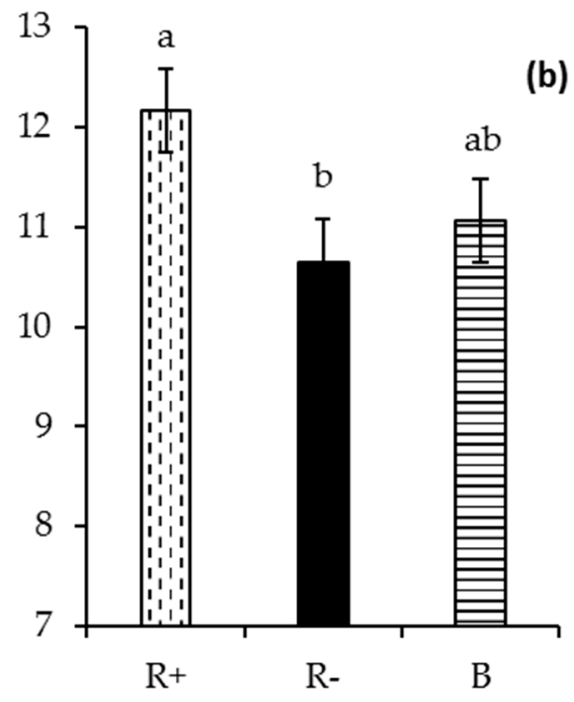

Residue management

Figure 2. Effects of crop rotation (a) and crop residue management (b) on cumulative carbon input $\left(\mathrm{Mg} \mathrm{ha}^{-1}\right)$ for six seasons (2015-2017). Different lowercase letters indicate significant differences at $p<0.001$. 


\subsection{Soil Organic Carbon}

Four-way interaction of season $\times$ tillage $\times$ crop rotation $\times$ residue management was not significant with respect to SOC at both the $0-5$ and $5-10 \mathrm{~cm}$ soil depth. Similarly, three-way interaction of tillage $\times$ crop rotation $\times$ crop residue management was not significant $(p>0.05)$ at both soil depths. The interaction of season $\times$ tillage was significant $(p<0.01)$ only at the $0-5 \mathrm{~cm}$ depth, while season $\times$ crop rotation was significant $(p<0.05)$ only at the $5-10 \mathrm{~cm}$ depth. The main effects of season $(p<0.01)$, tillage $(p<0.01)$, and crop residue management $(p>0.05)$ were significant with respect to SOC only at the $0-5 \mathrm{~cm}$ depth. However, only the main effects of crop rotation significantly affected $(p<0.01) \mathrm{SOC}$ at the $5-10 \mathrm{~cm}$ depth.

At the $0-5 \mathrm{~cm}$ depth, NT had higher SOC compared to CT across all seasons (Table 4). The highest and the least SOC were both observed in season 3 under NT $(1.22 \%)$ and CT $(0.86 \%)$, respectively. With respect to residue management, the highest SOC was observed under R+ $(1.10 \%)$, followed by B $(1.0 \%)$ and the least was in R- $(0.96 \%)$ (Figure 3a). The highest SOC at the $5-10 \mathrm{~cm}$ depth was observed in season 4 under the MOM $(1.05 \%)$ rotation, while season 3 under the MFM $(0.75 \%)$ rotation had the least SOC (Figure 4). At the 5-10 cm depth, SOC was in the following order: MOM $>M V M>M F M$ (Figure 3b).

Table 4. Interactive effects of season and tillage on soil organic carbon (\%) at the $0-5 \mathrm{~cm}$ depth in a maize-based conservation agriculture system in a semiarid climate in South Africa.

\begin{tabular}{ccccccc}
\hline & $\begin{array}{c}\text { Winter 2015 } \\
\text { (Season 1) }\end{array}$ & $\begin{array}{c}\text { Summer } \\
\mathbf{2 0 1 5 / 1 6} \\
\text { (Season 2) }\end{array}$ & $\begin{array}{c}\text { Winter 2016 } \\
\text { (Season 3) }\end{array}$ & $\begin{array}{c}\text { Summer } \\
\mathbf{2 0 1 6 / 2 0 1 7} \\
\text { (Season 4) }\end{array}$ & $\begin{array}{c}\text { Winter 2017 } \\
\text { (Season 5) }\end{array}$ & $\begin{array}{c}\text { Summer } \\
\mathbf{2 0 1 7 / 2 0 1 8} \\
\text { (Season 6) }\end{array}$ \\
\hline $\mathrm{NT}$ & $1.00 \mathrm{bcdef}$ & $1.1 \mathrm{ab}$ & $1.22 \mathrm{a}$ & $1.11 \mathrm{ab}$ & $1.10 \mathrm{ab}$ & $1.08 \mathrm{bc}$ \\
$\mathrm{CT}$ & $0.92 \mathrm{def}$ & $1.00 \mathrm{bcde}$ & $0.86 \mathrm{f}$ & $1.04 \mathrm{bcd}$ & $0.95 \mathrm{cdef}$ & $0.87 \mathrm{ef}$ \\
\hline
\end{tabular}

NT, no-till; CT, conventional tillage. Different lowercase letters indicate significant differences at $p<0.01$.

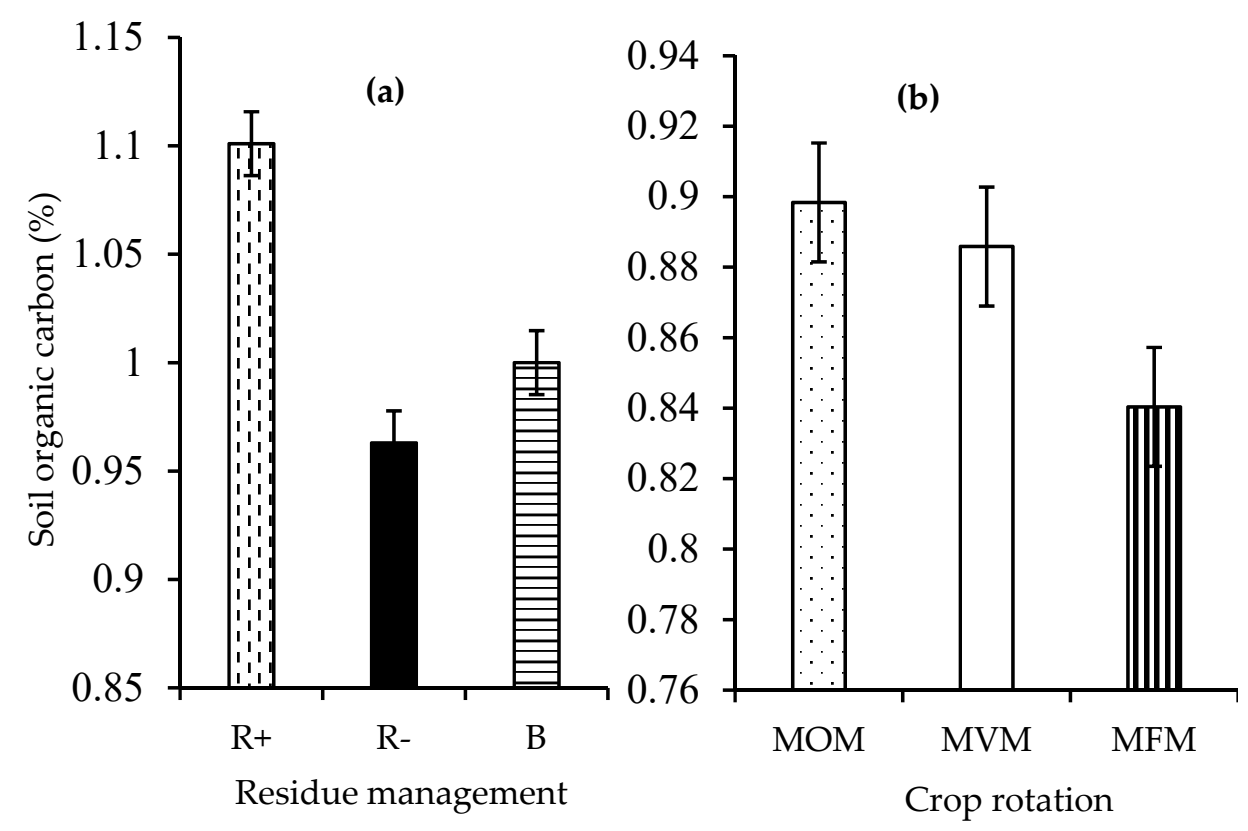

Figure 3. Effect of (a) crop residue management and crop rotation (b) on soil organic carbon at the $0-5 \mathrm{~cm}$ and $5-10 \mathrm{~cm}$ depths, respectively. 


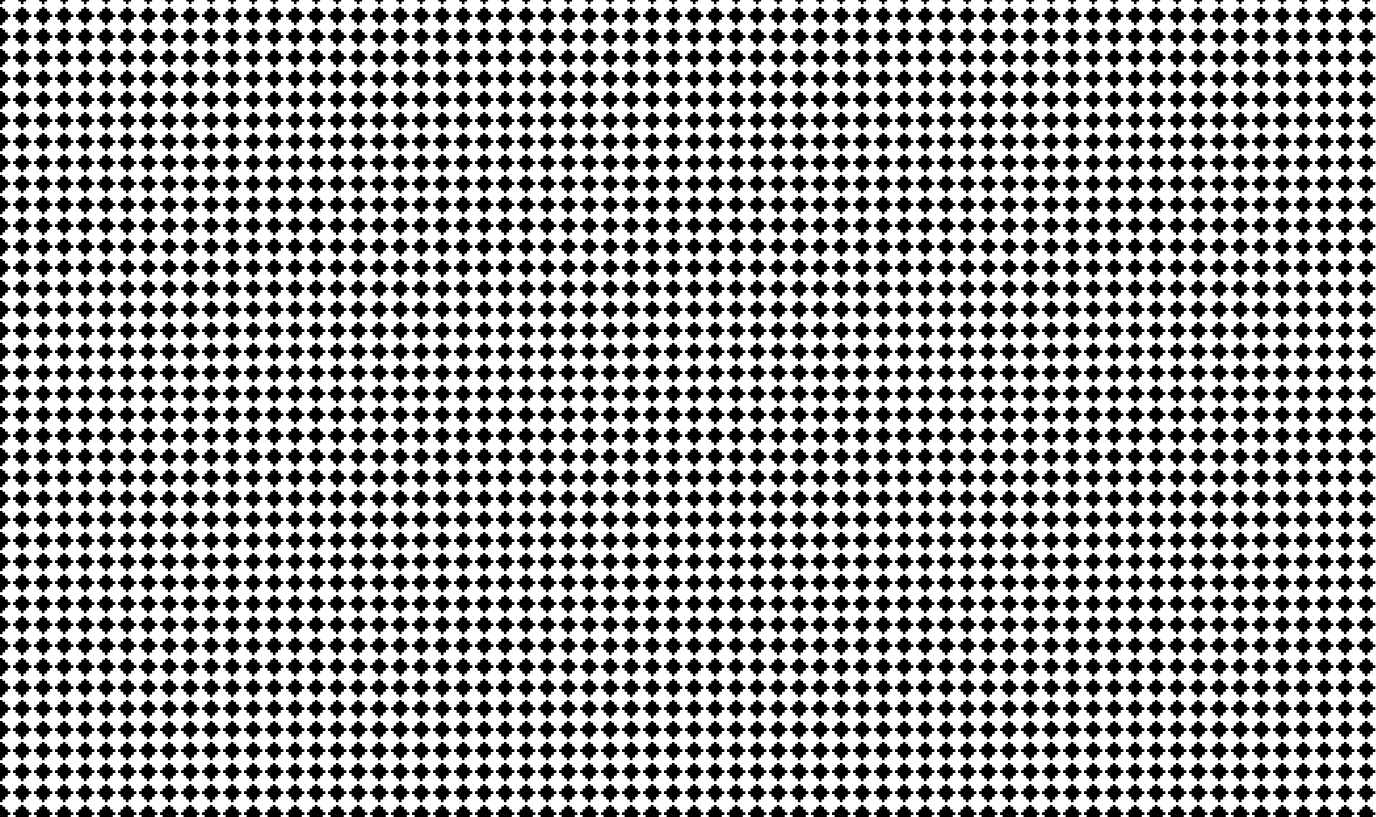

Figure 4. Interactive effects of season and crop rotation on soil organic carbon at the $5-10 \mathrm{~cm}$ depth in a maize-based conservation agriculture system in a semiarid climate in South Africa. Different lowercase letters indicate significant differences at $p<0.001$.

\subsection{Maize Yield Components and Grain Yield}

No significant three-way interactions of tillage $\times$ crop rotation $\times$ crop residue management were observed $(p>0.05)$ with respect to thousand grain mass of maize (TGM), final plant height, and maize grain yield in the 2015/2016, 2016/2017, and 2017/2018 summer seasons. The interaction of tillage $\times$ crop rotation was highly significant $(p<0.001)$ with respect to residue management and TGM only in the 2015/2016 summer season, whereas all the two-way interactions had no effect on TGM, final plant height, and maize grain yield in all summer seasons. The main effect of crop residue management significantly affected TGM $(p>0.01)$ in 2015/2016 summer season. Only the main effect of tillage significantly $(p<0.05)$ affected the final plant height in the 2015/2016 and 2017/2018 summer seasons. Maize grain yield was significantly $(p<0.05)$ affected by crop residue management in 2015/2016 and 2016/2017 summer seasons. Crop residue retention produced a significantly lower TGM in NT (246.6 g) compared to CT (295.9 g) (Figure 5), while amending the soil with biochar and removing crop residues did not affect the TGM under both NT and CT treatments.

In both the 2015/2016 and 2017/2018 summer seasons, the final height of maize was higher in CT relative to NT treatments (Figure 6). The final plant height was 5.1\% and 5\% higher in CT relative to NT in 2015/2016 and 2017/2018, respectively, (Figure 6a,b).

In the 2015/2016 summer season, maize grain yield was significantly higher in plots with $\mathrm{R}-$ (5.18 $\mathrm{Mg} \mathrm{ha}^{-1}$ ) compared to plots with $\mathrm{R}+\left(4.26 \mathrm{Mg} \mathrm{ha}^{-1}\right)$ (Table 5). In the same season, B (4.42 $\mathrm{Mg} \mathrm{ha}^{-1}$ ) application was not statistically different to both $\mathrm{R}-$ and $\mathrm{R}+$. On the other hand, application of $\mathrm{B}$ (4.81 Mg ha ${ }^{-1}$ ) significantly increased maize grain yield compared to both $\mathrm{R}+\left(3.38 \mathrm{Mg} \mathrm{ha}^{-1}\right)$ and $\mathrm{R}-$ (3.08 Mg ha-1) in the 2016/2017 season, while the yield in the R+ and R- was not significantly different in the same season (Table 5). 


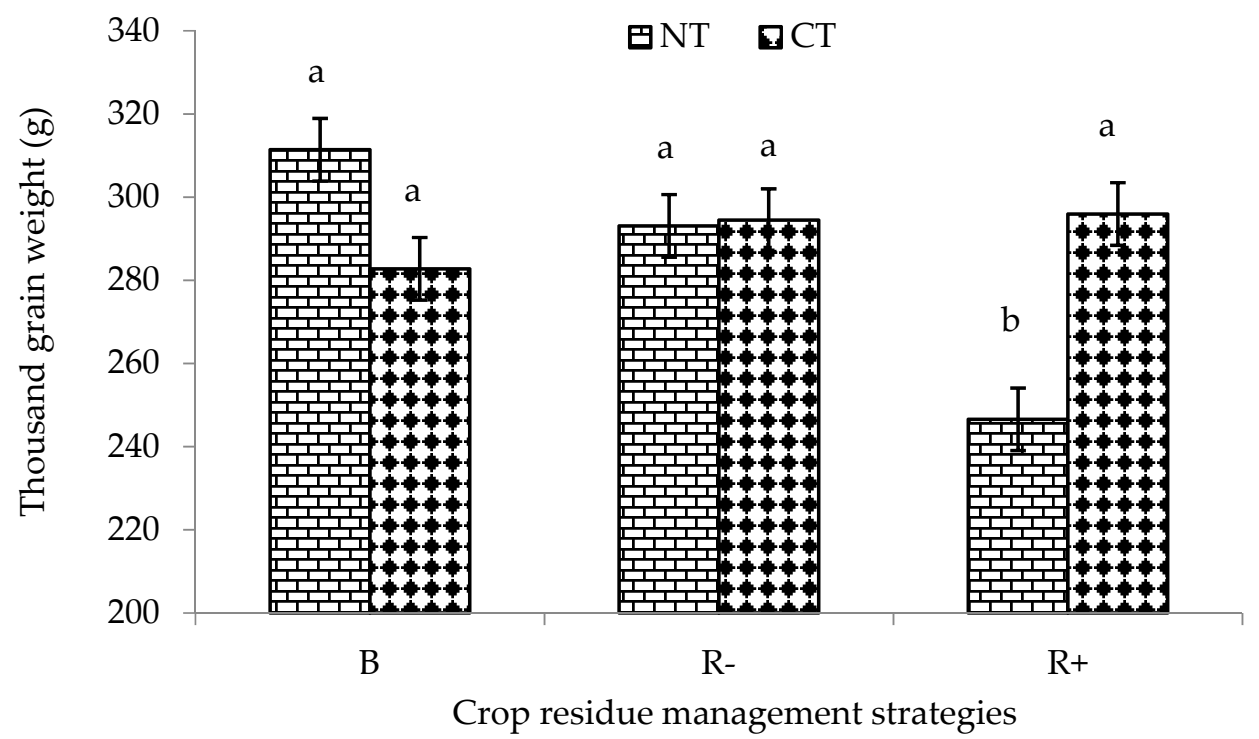

Figure 5. Interactive effects of tillage $\times$ crop residue management on the weight of a thousand grains in a maize-based conservation agriculture system in a semiarid climate in South Africa during the 2015/2016 summer season. Different lowercase letters indicate significant differences at $p \leq 0.001$.

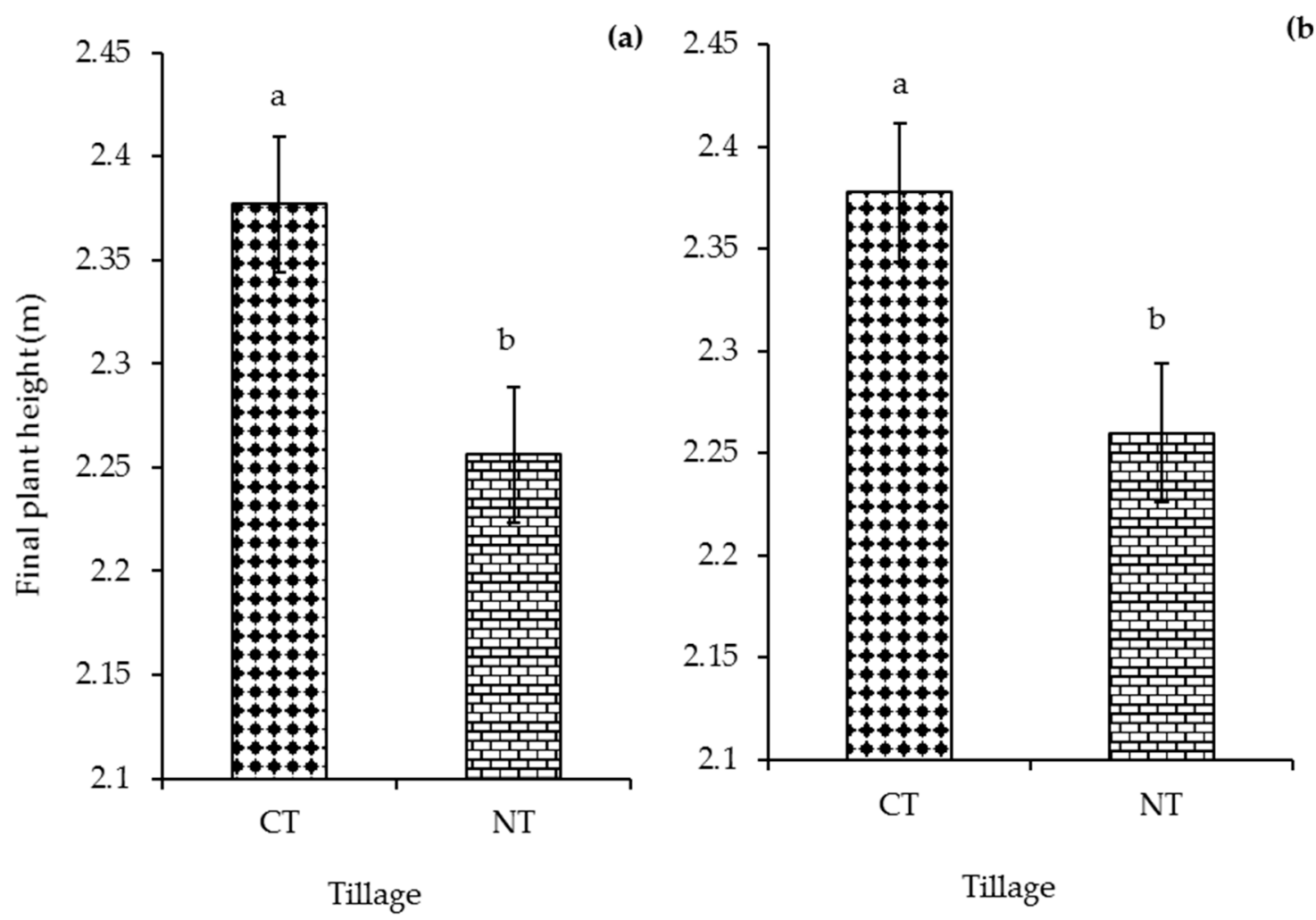

Figure 6. Effect of tillage on the final plant height of a maize crop in the (a) 2015/2016 and (b) 2017/2018 summer seasons in a semiarid climate in South Africa. Different lowercase letters indicate significant differences at $p \leq 0.05$. 
Table 5. Season, tillage, crop rotation, and residue management effects on the maize grain yield recorded during the 2015/2016, 2016/2017 and 2017/2018 summer seasons at the University of Fort Hare research farm.

\begin{tabular}{|c|c|c|c|}
\hline & 2015/2016 Season & 2016/2017 Season & 2017/2018 Season \\
\hline & \multicolumn{3}{|c|}{$\operatorname{Mg~ha}^{-1}$} \\
\hline \multicolumn{4}{|l|}{ Tillage } \\
\hline $\mathrm{CT}$ & 4.85 & 3.68 & 4.92 \\
\hline NT & 4.39 & 3.83 & 4.70 \\
\hline $\mathrm{LSD}_{0.05}$ & ns & ns & ns \\
\hline \multicolumn{4}{|l|}{ Crop rotation } \\
\hline MFM & 4.52 & 3.69 & 4.85 \\
\hline MOM & 4.48 & 3.91 & 4.54 \\
\hline MVM & 4.87 & 3.66 & 5.04 \\
\hline $\mathrm{LSD}_{0.05}$ & ns & ns & ns \\
\hline \multicolumn{4}{|l|}{ Residue management } \\
\hline Residue removed & $5.18 \mathrm{a}$ & $3.20 \mathrm{~b}$ & 5.15 \\
\hline Residue retained & $4.26 \mathrm{~b}$ & $3.38 b$ & 4.59 \\
\hline Biochar & $4.42 \mathrm{ab}$ & $4.53 a$ & 4.68 \\
\hline $\mathrm{LSD}_{0.05}$ & 0.76 & 0.60 & ns \\
\hline
\end{tabular}

$\mathrm{LSD}_{0.05}$, least significant difference at the 0.05 level of significance; ns, not significant; NT, no-till; CT, conventional tillage; MFM, maize-fallow-maize; MOM, maize-oat-maize; MVM, maize-vetch-maize.

\section{Discussion}

\subsection{Aboveground Biomass Production and Carbon Input from Plant Residues}

The high cumulative biomass yields in the study highlight the importance of winter cover crops in the farming systems of the Eastern Cape Province. The increased biomass production in MOM rotation is possibly due to the fast-growing and tillering ability of white oats as compared to grazing vetch [48]. The study concurs with results obtained by Murungu et al. [19] and Muzangwa et al. [49], who reported that inclusion of a cereal cover crop produced more cumulative dry biomass compared to grazing vetch and fallow treatments. The high crop biomass achieved in this study translates to high C input. Garcia-Gonzalez et al. [50] also observed a high cumulative C input in a cereal cover crop compared to grazing vetch. In this study, the crop biomass yield of grazing vetch was low possibly due to the effect of planting time. The crop was planted at the end of May when the temperatures were low for the optimum germination and growth of the crop (Figure 7a). In the 2017 winter season, the crop was grazed by cows; this especially affected the grazing vetch biomass yield, the oat cover crop was able to regrow (Figure $7 \mathrm{~b}$ ). However, the high crop biomass yield in plots with cover crops relative to fallow plots can also be the best approach to address the needs of the crop and livestock enterprises in mixed cropping systems in many smallholder farms in the central Eastern Cape Province. The crop biomass yield was more than the level regarded as necessary for the success of CA, which is 6-10 tha ${ }^{-1}$ dry matter per year [51]. According to Ferreira et al. [52], the sustained input of the large quantities of biomass to the soil surface creates a positive impact on agricultural and environmental sustainability. 


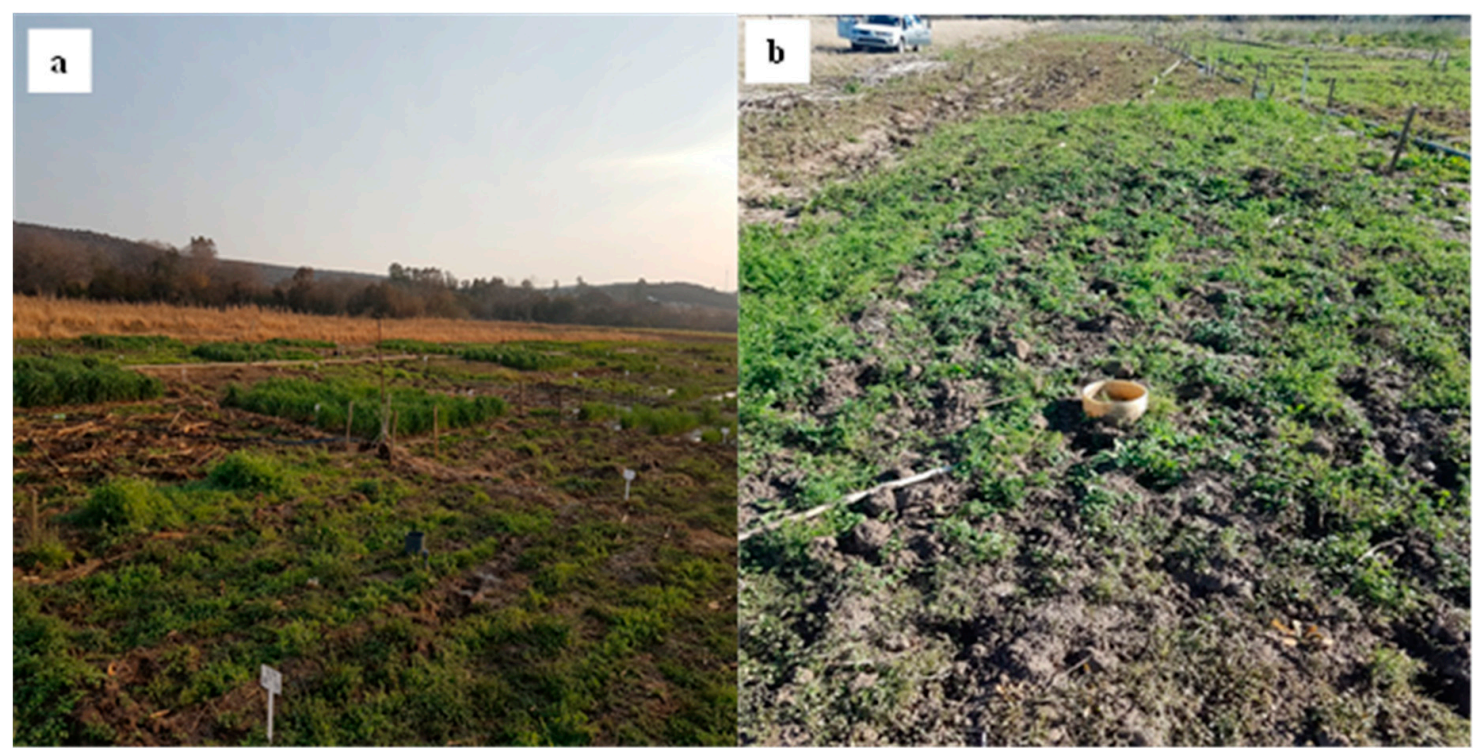

Figure 7. Picture showing (a) slow growth of grazing vetch cover crop relative to oat and (b) grazing vetch crop after damage by cattle.

\subsection{Soil Organic Carbon}

The lack of various and significant interactions in this study suggest that SOC is not affected by CA in the short term. This was also suggested by Blanco-Canqui et al. [53] and Poeplau and Don [54]. However, tilling the soil in the Province hastens the loss of SOC through excessive removal of crop biomass after harvest and higher decomposition rate due to increased microbial activity at the soil surface. This is evidenced by the observed higher SOC under NT relative to CT at the $0-5 \mathrm{~cm}$ soil depth (Table 4) in all six cropping seasons. The gradual decrease SOC in the CT plots between the winter 2015 season and the summer 2017/2018 season is possibly because of the disruption in C cycling caused by tillage. These results concur with studies by Govaerts et al. [55] and Ella et al. [56]. The higher amount of SOC in the top 0-5 cm compared to lower depths was due to the presence of crop residues on the soil surface. Slight increase of SOC at the soil surface is necessary to control erosion, water infiltration, and conservation of nutrients, and is related with the soil quality [57].

In this study, $\mathrm{R}+$ increased SOC at the $0-5 \mathrm{~cm}$ depth relative to both $\mathrm{B}$ and $\mathrm{R}-$ treatments. Higher SOC in the R+ treatment can be attributed to the presence of residues which are broken down and decomposed by soil fauna [58]. Similar results were observed by Kassam et al. [12], Dalal et al. [59], Li et al. [60], Rusinamhodzi et al. [61], and Turmel et al. [31]. The low SOC in B treatments can be attributed to the low quantities applied in the study (Table 2). The response of soil to biochar amended is dependent on the amount and quality of biochar used [36]. According to Monnie [62], corn cob biochar applied at rates that are $20 \mathrm{t} \mathrm{ha}^{-1}$ did not show any significant soil improvements. Furthermore, the low SOC content in B treatments can possibly be explained by preferential lateral movement of biochar due to low mass per volume and vertical migration of biochar due to solute transport and bioturbation along the soil profile [63].

\subsection{Maize Grain Yield and Yield Components}

The lack of significant differences between NT and CT in terms of maize yield shows that the smallholder farmers in the EC can potentially switch from soil tilling without any significant yield penalty. Paudel et al. [28] reported similar results under rain-fed conditions in Nepal. According to Giller et al. [64] and Thierfelder et al. [65], benefits of CA are not always immediate. For example, in arid and semiarid conditions, CA may increase crop yield through improving soil fertility through C sequestration and water conservation [66]. On the other hand, it can have negative impacts on crop 
yield by altering soil physiochemical and biological conditions, such as decreasing soil temperatures in temperate areas and seasons with low temperature, thus aggravating weeds [23].

The low maize grain yield in the plots with residues relative to R- and B treatments in the 2015/2016 summer season can possibly be due to the high pest and disease problem that was encountered in these treatments. Cut worms, rodents, and maize stock borer attacks were high, especially in plots with a combination of NT and R+. Wolfe and Eckert [67] and Al-Kaisi and Kwaw-Mensah [68] also reported that excessive crop residues left on the soil surface, such as in NT, can potentially reduce plant emergence, N mineralization, and crop growth, resulting in lower crop yields. In the 2016/2017 summer season, the significantly higher maize grain yields in the B treatments can be explained by the ability of biochar to adsorb nutrients and release them into the soil for uptake by plants [69]. The maize yields in the same year were low relative to the other seasons because of a combination of the low rainfall received during the crop growing season and the effect of pest incidences on crop stand. Birds and rodents damaged the crops, especially in the plots with $\mathrm{R}+$. The residues provided cover for the pests and maintained a moist soil surface that made it easy for the crows (Corvus) to dig out the germinating maize seeds and crops. The attacks were so severe that much of the crop had to be replanted well after the maize planting dates (end of January). The inconsistent maize yields across seasons in this study can be attributed to the variability of rainfall. This is also corroborated by Cairns et al. [70], who reported that rainfall erraticism causes yields in a CA system not to stabilise as expected.

\section{Conclusions}

This study showed that the adoption of crop rotations and residue management practices results in an increase in crop biomass, which is also positively correlated $C$ input. Furthermore, changes in SOC due to management practices occurred too slowly to reflect in maize grain yields in the short-term. Generally, the variability of maize grain yield in the three summer seasons makes the results inconclusive in the short term. However, the lack of significant differences between CA and CT means that adoption of CA in the Eastern Cape Province neither leads to immediate benefits nor losses in maize yield. Therefore, smallholder farmers in the Eastern Cape Province can potentially switch from CT to NT without any significant yield penalty. Addition of biochar did not result in an obvious improvement in both soil $\mathrm{C}$ input and crop yield in the current study. However, the fact that it performed more or less than retaining crop residues relative to crop productivity warrants further studies, especially when significantly large quantities are accrued. Therefore, continued evaluation of treatments for a medium- to long-term period is highly recommended.

Author Contributions: P.N. designed, setup, collected data, analyzed data, and wrote the manuscript. C.C. designed, setup, collected data, analyzed data, and wrote the manuscript. T.A. wrote the manuscript. All authors have read and agreed to the published version of the manuscript.

Acknowledgments: We are thankful to the National Research Foundation (NRF) of South Africa (Grant number CSUR14080586821) and the Govan Mbeki Research and Development Centre (GMRDC), University of Fort Hare, for the supporting the study through funding.

Conflicts of Interest: The authors declare no conflict of interest.

\section{References}

1. Muzangwa, L.; Mnkeni, P.N.S.; Chiduza, C. Assessment of Conservation Agriculture Practices by Smallholder Farmers in the Eastern Cape Province of South Africa. Agronomy 2017, 7, 46. [CrossRef]

2. Pokharel, D.; Jha, R.K.; Tiwari, T.P.; Gathala, M.K.; Shrestha, H.K.; Panday, D. Is conservation agriculture a potential option for cereal-based sustainable farming system in the Eastern Indo-Gangetic Plains of Nepal? Cogent Food Agric. 2018, 4, 1557582. [CrossRef]

3. Giller, K.E.; Andersson, J.A.; Corbeels, M.; Kirkegaard, J.; Mortensen, D.; Erenstein, O.; Vanlauwe, B. Beyond conservation agriculture. Front. Plant Sci. 2015, 6, 870. [CrossRef] [PubMed] 
4. Mnkeni, P.N.S.; Chiduza, C.; Modi, A.T.; Stevens, J.B.; Monde, N.; van der Stoep, I.; Dladla, R. Best management practices for smallholder farming on two irrigation schemes in the Eastern Cape and KwaZulu-Natal through participatory adaptive research. WRC Rep. 2010, 478, 359.

5. Von Loeper, W.; Musango, J.; Brent, A.; Drimie, S. Analysing challenges facing smallholder farmers and conservation agriculture in South Africa: A system dynamics approach. S. Afr. J. Econ. Manag. Sci. 2016, 19, 747-773. [CrossRef]

6. Mazvimavi, K.; Twomlow, S. Socio-economic and institutional factors influencing adoptionof conservation farming by vulnerable households in Zimbabwe. Agric. Syst. 2009, 101, 20-29. [CrossRef]

7. Valbuena, D.; Erenstein, O.; Tui, S.H.-K.; Abdoulaye, T.; Claessens, L.; Duncan, A.J.; Gérard, B.; Rufino, M.C.; Teufel, N.; van Rooyen, A. Conservation Agriculture in mixed crop-livestock systems: Scoping crop residue trade-offs in Sub-Saharan Africa and South Asia. Field Crop. Res. 2012, 132, 175-184. [CrossRef]

8. Thierfelder, C.; Mombeyarara, T.; Mango, N.; Rusinamhodzi, L. Integration of conservation agriculture in smallholder farming systems of southern Africa: Identification of key entry points. Int. J. Agric. Sustain. 2013, 11, 317-330. [CrossRef]

9. Khorami, S.S.; Kazemeini, S.A.; Afzalinia, S.; Gathala, M.K. Changes in soil properties and productivity under different tillage practices and wheat genotypes: A short-term study in Iran. Sustainability 2018, 10, 3273. [CrossRef]

10. Derpsch, R.; Friedrich, T.; Kassam, A.; Hongwen, L. Current status of adoption of no-till farming in the world and some of its main benefits. Int. J. Agric. Biol. Eng. 2010, 3, 1-25.

11. Food and Agriculture Organization [FAO]. Conservation Agriculture. 2008. Available online: http: //www.fao.org/ag/ca/1a.html (accessed on 4 August 2015).

12. Kassam, A.; Friedrich, T.; Shaxson, F.; Pretty, J. The spread of conservation agriculture: Justification; sustainability and uptake. Int. J. Agric. Sustain. 2009, 7, 292-320. [CrossRef]

13. Delgado, J.A.; Groffman, P.M.; Nearing, M.A.; Goddard, T.; Reicosky, D.; Lal, R.; Kitchen, N.R.; Rice, C.W.; Towery, D.; Salon, P. Conservation practices to mitigate and adapt to climate change. J. Soil Water Conserv. 2011, 66, 118-129. [CrossRef]

14. Lal, R. Enhancing crop yields in the developing countries through restoration of the soil organic carbon pool in agricultural lands. Land Degrad. Dev. 2005, 17, 197-209. [CrossRef]

15. Sithole, N.; Magwaza, L.S.; Mafongoya, P.L. Conservation agriculture and its impact on soil quality and maize yield: A South African perspective. Soil Tillage Res. 2016, 162, 55-67. [CrossRef]

16. Zuber, S.M.; Behnke, G.D.; Nafziger, E.D.; Villamil, M.B. Carbon and Nitrogen Content of Soil Organic Matter and Microbial Biomass under Long-Term Crop Rotation and Tillage in Illinois, USA. Agriculture 2018, 8, 37. [CrossRef]

17. Nyamangara, J.; Nyengerai, K.; Masvaya, E.N.; Tirivavi, R.; Mashingaidze, N.; Mupangwa, W.; Dimes, J.; Hove, L.; Twomlow, S. Effect of conservation agriculture on maize yield in the semi-arid areas of Zimbabwe. Exp. Agric. 2014, 50, 159-177. [CrossRef]

18. Ding, G.; Liu, X.; Herbert, S.; Novak, J.; Amarasiriwardena, D.; Xing, B. Effect of cover crop management on soil organic matter. Geoderma 2006, 130, 229-239. [CrossRef]

19. Murungu, F.; Chiduza, C.; Muchaonyerwa, P. Mulch effects on soil moisture productivity in warm-temperate climate of South Africa. Soil Tillage Res. 2011, 112, 58-65. [CrossRef]

20. Murungu, F.; Chiduza, C.; Muchaonyerwa, P.; Mnkeni, P. Decomposition, nitrogen and phosphorus mineralization from winter-grown cover crop residues and suitability for a smallholder farming system in South Africa. Nutr. Cycl. Agroecosyst. 2011, 89, 115-123. [CrossRef]

21. Thierfelder, C.; Wall, P.C. Effects of conservation agriculture on soil quality and productivity in contrasting agro-ecological environments of Zimbabwe. Soil Use Manag. 2012, 28, 209-222. [CrossRef]

22. Dube, E.; Chiduza, C.; Muchaonyerwa, P. Conservation agriculture effects on plant nutrients and maize grain yield after four years of maize-winter cover crop rotations. S. Afr. J. Plant Soil 2013, 30, 227-232. [CrossRef]

23. Araya, T.; Cornelis, W.M.; Nyssen, J.; Govaerts, B.; Bauer, H.; Gebreegziabher, T.; Oicha, T.; Raes, D.; Sayre, K.D.; Haile, M.; et al. Effects of conservation agriculture on runoff, soil loss and crop yield under rainfed conditions in Tigray, Northern Ethiopia. Soil Use Manag. 2011, 27, 404-414. [CrossRef]

24. Zheng, C.; Jiang, Y.; Chen, C.; Sun, Y.; Feng, J.; Deng, A.; Song, Z.; Zhang, W. The impacts of conservation agriculture on crop yield in China depend on specific practices, crops and cropping regions. Crop J. 2014, 2, 289-296. [CrossRef] 
25. Araya, T.; Cornelis, W.M.; Nyssen, J.; Govaerts, B.; Getnet, F.; Bauer, H.; Raes, D.; Amare, K.; Haile, M.; Deckers, J. Medium-term effects of conservation agriculture for in situ soil and water management and crop productivity in the northern Ethiopian highlands. Field Crops Res. 2012, 132, 53-62. [CrossRef]

26. Mashingaidze, N.; Madakadze, C.; Twomlow, S.; Nyamangara, J.; Hove, L. Crop yield and weed growth under conservation agriculture in semi-arid Zimbabwe. Soil Tillage Res. 2012, 124, 102-110. [CrossRef]

27. Paul, B.K.; Vanlauwe, B.; Ayuke, F.; Gassner, A.; Hoogmoed, M.; Hurisso, T.; Koala, S.; Lelei, D.; Ndabamenye, T.; Six, J. Medium-term impact of tillage and residue management on soil aggregate stability, soil carbon and crop productivity. Agric Ecosyst. Environ. 2013, 164, 14-22. [CrossRef]

28. Paudel, B.; Radovich, T.J.K.; Chan-Halbrendt, C.; Crow, S.; Tamang, B.B.; Halbrendt, J.; Thapa, K. Effect of Conservation Agriculture on Maize-based Farming System in the Mid-hills of Nepal. Procedia Eng. 2014, 78, 327-336. [CrossRef]

29. Hatfield, J.L. Managing soils to achieve greater water use efficiency: A review. Agron. J. 2001, 93, $271-280$. [CrossRef]

30. Erenstein, O. Crop residue mulching in tropical and semi-tropical countries. An evaluation of research availability and other technological implications. Soil Tillage Res. 2002, 67, 115-133. [CrossRef]

31. Turmel, M.S.; Speratti, A.; Baudron, F.; Verhulst, N.; Govaerts, B. Crop residue management and soil health: A systems analysis. Agric. Syst. 2002, 134, 6-16. [CrossRef]

32. Van Ittersum, M.K.; Van Bussel, L.G.; Wolf, J.; Grassini, P.; Van Wart, J.; Guilpart, N.; Claessens, L.; de Groot, H.; Wiebe, K.; Mason-D'Croz, D.; et al. Can sub-Saharan Africa feed itself? Proc. Natl. Acad. Sci. USA 2016, 113, 14964-14969. [CrossRef] [PubMed]

33. Montgomery, D.R. Soil erosion and agricultural sustainability. Proc. Natl. Acad. Sci. USA 2007, 104, 13268-13272. [CrossRef] [PubMed]

34. Novotny, E.H.; Hayes, M.H.; Madari, B.E.; Bonagamba, T.J.; Azevedo, E.R.D.; Souza, A.A.D.; Song, G.; Nogueira, C.M.; Mangrich, A.S. Lessons from the Terra Preta de Índios of the Amazon region for the utilisation of charcoal for soil amendment. J. Braz. Chem. Soc. 2009, 20, 1003-1010. [CrossRef]

35. Yao, Y.; Gao, B.; Zhang, M.; Inyan, M.; Zimmerman, A.R. Effect of biochar amendment on sorption and leaching of nitrate, ammonium and phosphate in a sandy soil. Chemosphere 2012, 89, 1467-1471. [CrossRef]

36. Nyambo, P.; Taeni, T.; Chiduza, C.; Araya, T. Effects of Maize Residue Biochar Amendments on Soil Properties and Soil Loss on Acidic Hutton Soil. Agronomy 2018, 8, 256. [CrossRef]

37. Lehmann, J.; Joseph, S. Biochar for environmental management: An introduction, Biochar for Environmental Management. Sci. Technol. 2009, 1, 1-12.

38. Novak, J.M.; Lima, I.M.; Xing, B.; Gaskin, J.W.; Steiner, C.; Das, K.C.; Ahmedna, M.; Rehrah, D.; Watts, D.W.; Busscher, W.J.; et al. Charcaterization of designer biochar produced at different temperatures and their effects on a loamy sand. Ann. Environ. Sci. 2009, 3, 195-206.

39. Lehmann, J.; Da Silva, J.P., Jr.; Steiner, C.; Nehls, T.; Zech, W.; Glaser, B. Nutrient availability and leaching in an archaeological Anthrosol and a Ferralsol of the Central Amazon basin: Fertilizer, manure and charcoal amendments. Plant Soil 2003, 249, 343-357. [CrossRef]

40. IUSS Working Group WRB. World reference base for soil resources. In World Soil Resources Report No. 103; FAO: Rome, Italy, 2006.

41. Mandiringana, O.T.; Mnkeni, P.N.S.; Mkile, Z.; Van Averbeke, W.; Van Ranst, E.; Verplancke, H. Mineralogy and fertility status of selected soils of the Eastern Cape Province, South Africa. Comms. Soil Sci. Plant Anal. 2005, 36, 2431-2446. [CrossRef]

42. Dube, E.; Chiduza, C.; Muchaonyerwa, P. Conservation agriculture effects on soil organic matter on a Haplic Cambisol after four years of maize-oat and maize-grazing vetch rotations in South Africa. Soil Tillage Res. 2012, 123, 21-28. [CrossRef]

43. Gura, I.; Mnkeni, P.N.S. Crop rotation and residue management effects under no till on the soil quality of a Haplic Cambisol in Alice, Eastern Cape, South Africa. Geoderma 2019, 337, 927-934. [CrossRef]

44. Verhulst, N.; Cox, R.; Govaerts, B. Yield and Yield Components: A Practical Guide for Comparing Crop Management Practices; CIMMYT: Houston, TX, USA, 2013.

45. Agri Laboratory Association of Southern Africa [AgriLASA]. Soil Handbook; Pretoria (South Africa): Agri Laboratory Association of Southern Africa: Pretoria, South Africa, 2004.

46. LECO Truspec CN Carbon/Nitrogen Determinator Instructions Manual; LECO Corporation: St Joseph, MO, USA, 2003. 
47. Gomez, K.A.; Gomez, A.A. Statistical Procedures for Agricultural Research, 2nd ed.; A Wiley Inter-Science Publication: Singapore, 1984; pp. 1-627.

48. Alemu, B.; Melaku, S.; Prasad, N.K. Effects of varying seed proportions and harvesting stages on biological compatibility and forage yield of oats (Avena sativa L.) and vetch (Vicia villosa R.) mixtures. Livest. Res. Rural Dev. 2007, 19, 12.

49. Muzangwa, L.; Chiduza, C.; Muchaonyerwa, P. Biomass production, weed suppression, nitrogen and phosphorus uptake in white oat (Avena sativa L.) and grazing vetch (Vicia dasycarpa L.) cover crop bicultures under an irrigated no-tillage system. South Afr. J. Plant Soil 2012, 29, 135-141. [CrossRef]

50. Garcia-Gonzalez, I.; Hontoria, C.; Gabriel, J.L.; Alonso-Ayuso, M.; Quemada, M. Cover crops to mitigate soil degradation and enhance soil functionality in irrigated land. Geoderma 2018, 322, 81-88. [CrossRef]

51. Dube, E.; Chiduza, C.; Muchaonyerwa, P. High biomass yielding winter cover crops can improve phosphorus availability in soil. S. Afr. J. Sci. 2014, 110, 1-4. [CrossRef]

52. Ferreira, K.N.; Iverson, T.M.; Maghlaoui, K.; Barber, J.; Iwat Ferreira, K.N.; Iverson, T.M.; Maghlaoui, K.; Barber, J.; Iwata, S. Architecture of the photosynthetic oxygen-evolving center. Science 2004, 303, 1831-1838. [CrossRef]

53. Blanco-Canqui, H.; Shaver, T.M.; Lindquist, J.L.; Shapiro, C.A.; Elmore, R.W.; Francis, C.A.; Hergert, G.W. Cover crops and ecosystem services: Insights from studies in temperate soils. Agron. J. 2015, 107, 2449-2474. [CrossRef]

54. Poeplau, C.; Don, A. Carbon sequestration in agricultural soils via cultivation of cover crops-A meta-analysis. Agric. Ecosyst. Environ. 2015, 200, 33-41. [CrossRef]

55. Govaerts, B.; Sayre, K.D.; Lichter, K.; Dendooven, L.; Deckers, J. Influence of permanent raised bed planting and residue management on physical and chemical soil quality in rain fed maize/wheat systems. Plant Soil 2007, 291, 39-54. [CrossRef]

56. Ella, V.B.; Reyes, M.R.; Mercado, A.J.; Ares, A.; Padre, R. Conservation agriculture increases soil organic carbon and residual water content in upland crop production systems. Eurasian J. Soil Sci. 2016, 5, $24-29$. [CrossRef]

57. Moussadek, R.; Mrabet, R.; Dahan, R.; Zouahri, A.; El Mourid, M.; Van Rans, E. Tillage System Affects Soil Organic Carbon Storage and Quality in Central Morocco. Appl. Environ. Soil Sci. 2014, 654796. [CrossRef]

58. Luca, E.F.; Chaplot, V.; Mutema, M.; Feller, C.; Ferreira, M.L.; Cerri, C.C.; Couto, H.T.Z. Effect of conversion from sugarcane preharvest burning to residues green-trashing on SOC stocks and soil fertility status: Results from different soil conditions in Brazil. Geoderma 2018, 310, 238-248. [CrossRef]

59. Dalal, R.C.; Allen, D.E.; Wang, W.J.; Reeves, S.; Gibson, I. Organic carbon and total nitrogen stocks in a Vertisol following 40 years of no-tillage, crop residue retention and nitrogen fertilisation. Soil Tillage Res. 2011, 112, 133-139. [CrossRef]

60. Li, L.-1.; Huang, G.-b.; Zhang, R.; Bill, B.; Guangdi, L.; Kwong, Y.C. Benefits of Conservation Agriculture on Soil and Water Conservation and Its Progress in China. Agric. Sci. China 2011, 10, 850-859. [CrossRef]

61. Rusinamhodzi, L.; Corbeels, M.; van Wijk, M.T.; Rufino, M.C.; Nyamangara, J.; Giller, K.E. A meta-analysis of long-term effects of conservation agriculture on maize grain yield under rain-fed conditions. Agron. Sustain. Dev. 2011, 31, 657-673. [CrossRef]

62. Monnie, F. Effect of Biochar on Soil Physical Properties, Water Use Efficiency, and Growth of Maize in a Sandy Loam Soil. Ph.D. Thesis, University of Ghana, Accra, Ghana, 2016.

63. Katterer, T.; Roobroeck, D.; Andrén, O.; Kimutai, G.; Karltun, E.; Kirchmann, H.; Nyberg, G.; Vanlauwe, B.; de Nowina, K.R. Biochar addition persistently increased soil fertility and yields in maize-soybean rotations over 10 years in sub-humid regions of Kenya. Field Crop. Res. 2019, 235, 18-26. [CrossRef]

64. Giller, K.E.; Witter, B.; Corbeels, M.; Tittonell, P. Conservation agriculture and smallholder farming in Africa: The heretics' view. Field Crop. Res. 2009, 114, 23-34. [CrossRef]

65. Thierfelder, C.; Rusinamhodzi, L.; Ngwira, A.; Mupangwa, W.; Nyagumbo, I.; Kassie, G.; Cairns, J. Conservation agriculture in Southern Africa: Advances in knowledge. Renew. Agric. Food Syst. 2015, 30, 328-348. [CrossRef]

66. Thierfelder, C.; Mutenje, M.; Mujeyi, A.; Mupangwa, W. Where is the limit? Lessons learned from long-term conservation agriculture research in Zimuto Communal Area, Zimbabwe. Food Secur. 2014, 7, 15. [CrossRef]

67. Wolfe, A.M.; Eckert, D.J. Crop sequence and surface residue effects on the performance of no-till corn grown on a poorly drained soil. Agron. J. 1999, 91, 363-367. [CrossRef] 
68. Al-Kaisi, M.M.; Kwaw-Mensah, D. Effect of tillage and nitrogen rate on corn yield and nitrogen and phosphorus uptake in a corn-soybean rotation. Agron. J. 2007, 99, 1548-1558. [CrossRef]

69. Ding, Y.; Liu, Y.; Liu, S.; Li, Z.; Tan, X.; Huang, X.; Zeng, G.; Zhou, L.; Zheng, B. Biochar to improve soil fertility. A review. Agron. Sustain. Dev. 2016, 36, 36. [CrossRef]

70. Cairns, J.E.; Hellin, J.; Sonder, K.; Araus, J.L.; MacRobert, J.F.; Thierfelder, C.; Prasanna, B.M. Adapting maize production to climate change in sub-Saharan Africa. Food Secur. 2013, 5, 345-360. [CrossRef]

(C) 2020 by the authors. Licensee MDPI, Basel, Switzerland. This article is an open access article distributed under the terms and conditions of the Creative Commons Attribution (CC BY) license (http://creativecommons.org/licenses/by/4.0/). 